\title{
Development of a Two-Way Evacuation Route Database Based on Interviews Conducted with Historic Preservation Area Residents
}

\author{
Nobuo Mishima \\ Professor Dr., Graduate School of Science and Engineering \\ Saga University, Saga-city, Saga 840-8502, Japan \\ Naomi Miyamoto \\ Fukuoka branch, Land Brain Co., Fukuoka 810-0001, Japan \\ Yoko Taguchi \\ Lecturer Dr., Graduate School of Science and Engineering \\ Saga University, Saga-city, Saga 840-8502, Japan \\ Keiko Kitagawa \\ Professor Dr., Faculty of Culture and Education \\ Saga University, Saga-city, Saga 840-8502, Japan

\section{Yong-Sun Oh} \\ Professor Dr., Department of Information Communication Engineering \\ Mokwon University, Seo-gu, Daejeon, 302-729, Korea \\ Sun Gyu Park \\ Professor Dr., Division of Architecture \\ Mokwon University, Seo-gu, Daejeon, 302-729, Korea
}

\begin{abstract}
It has been determined that two-way evacuation routes that connect houses to evacuation sites should be developed to protect residents of historic preservation areas from future disasters. These routes are required because traditional buildings and other historic spatial elements are located close to each other. It is important to understand residents' perceptions of evacuation routes that connect their houses to temporary safe places to develop evacuation system strategies that include effective two-way evacuation routes. This paper describes a procedure used to construct a two-way evacuation route database designed to preserve two study areas that was based on an interview survey conducted with area residents. The resulting database contained residents' perceptions of evacuation routes. The database contains categorized spatial problems related to these routes that can be used for future research.
\end{abstract}

Key words: Disaster prevention, Historic area, Evacuation routes, Residents' perceptions, Evacuation Planning Database.

\section{INTRODUCTION}

1.1 Background of Study

Historic preservation areas are particularly vulnerable to

This is an excellent paper selected from the papers presented at ICCC 2012.

*Corresponding author,Email :mishiman@cc.saga-u.ac.jp Manuscript received May. 06, 2013; revised May 30, 2013; accepted Jun 10, 2013 disasters because many people reside close together in wooden houses. Because the historic value of these areas must be protected, to protect its historic value, it can be difficult to widen narrow streets in an effort to prevent future disasters. Therefore, in some historic preservation areas in Japan, two exits for each house are required by law to prevent possible fire-related disasters. In addition, it has been recommended that residents determine two-way evacuation routes to connect their houses to temporary safe places to which residents can 
evacuate and take cover immediately after disasters because secondary street-side exits cannot be completely secured in historic preservation areas. During large disasters, streets may become blocked. Yet, no current laws require that evacuation routes be secured. Thus, finding ways to secure two-way evacuation routes is a crucial issue for individuals who reside in historic preservation areas.

With respect to disaster prevention for historic preservation areas, only a limited number of studies have focused on ways to determine two-way evacuation routes and on residents' perceptions of these routes. The goal of this study was to develop a method that could be used to create a basic database that analysts or strategy developers employed by research agencies or companies could access to develop evacuation plans for historic preservation areas. This database would include information related to problems encountered during the determination of two-way evacuation routes for historic preservation areas.

\subsection{Aim of Study}

This paper describes a procedure used to construct a basic database of two-way evacuation routes that could be used to preserve two selected historical preservation areas. This study was based on data collected during an interview survey of residents to discover problems related to the determination of evacuation routes in the study area.

\subsection{Literature Review}

Current research focused on evacuation route planning can be divided into several categories: behavioral analyses of evacuees, residents' perceptions, algorithms and programming methods, evacuation times, and evacuation databases. Behavioral analyses of evacuees examined the effects of a variety of different behavioral and managerial factors on evacuations [12], evacuees' speeds while ascending or descending stairs [3], and the effects of merging that occurs on staircases, as well as ways to ease or prevent merging under a variety of conditions [4]. Surveys have been conducted to analyze residents' perceptions of volcanic hazards [5], to clarify the risks of and reasons for evacuation [6], and to assess tourists' perceptions of hurricanes, based on forecasts [7]. Algorithms and programming methods were created to generalize optimal evacuation plans (e.g., models used to analyze building evacuability [8], to develop mathematical modeling to simulate evacuation problems [9], to develop GIS-based mapping of evacuation choices during earthquakes [10], to develop a new multiagent system (SimTread) that calculates the shortest walking times [11], and to develop an evacuation simulator [12]). Studies have evaluated evacuation times to determine optimal routes. Decision support systems have been implemented during evacuation planning. Previous studies included an evaluation of an evacuation plan by the use of a microscopic simulation model [13], an analysis of smoke exhaustion and evacuation times in the arcade of a traditional Korean market [14], the development of a heuristic method with an incremental data structure that relies on real-world scenarios [15], and a network optimization approach to address problems with evacuation planning that occur with short notice [16]. Finally, a number of studies have developed evacuation databases to be used in planning [17].

However, historic preservation areas are locations that are particularly vulnerable to disaster because many elderly people live close together in wooden houses. A number of previous studies examined disaster prevention plans for the protection of traditional buildings located in Kanazawa City, Japan [18], and assessed increased local safety because of the shortening of evacuation routes located in Senbon-syaka-do in Kyoto, Japan [19]. Street widths in these areas might be narrower than $4 \mathrm{~m}$. Thus, it can be difficult to widen these streets and maintain their historic value. These streets can easily become clogged or blocked during large disasters, such as great earthquakes and large fires that might destroy buildings and block exits. If preferred evacuation routes become blocked, residents must evacuate by other routes. Therefore, the determination of twoway evacuation routes for each house is one of the most critical aspects of disaster prevention for historic preservation area residents. However, this must be achieved in addition to the maintenance of the narrow path widths. A prior study investigated the effectiveness of historic wooden back doors in Kyoto [20]. In addition, in another study [21], we assessed evacuation routes used in a Japanese historic preservation area by conducting intensive interviews with its residents. Based on our results, we proposed the use of a procedure to determine evacuation route planning for that study area. Our results indicated that maintenance of the open space located at the center of the study area was a useful method that could be used to improve evacuation routes that connected the houses to primary evacuation sites [25]. However, it can be difficult to create a database of residents' perceptions for use in two-way evacuation route planning. Therefore, it is important to analyze residents' perceptions, as well as problems related to evacuation routes.

\section{METHOD OF STUDY}

\subsection{Study Areas}

2.1.1 Characteristics of study areas: Our study areas consisted of two important historical preservation districts comprised of traditional buildings that were designated under the Act on Protection of Cultural Properties in 2007. The areas are located close to one another and are situated on either side of the Hama River in Kashima City, Saga Prefecture. Both areas functioned historically as station towns located along the Nagasaki Road that was built in Edo era to connect Kokura and Nagasaki. One area is known as Hamashozu Machi Hamakanaya Machi (hereafter, Area A). It has been preserved as a local town that contains straw-roofed and tile-roofed wooden townhouses built alongside narrow streets (see Figure 1). The second area is known as Hamanaka Machi Happongi Shuku (hereafter, Area B). It has been preserved as a sakeproducing town that contains both tile-roofed wooden storehouses and sake factories built close together (see Figure 2). Therefore, these two areas are more vulnerable than other historic preservation areas or other dense urban areas filled with wooden structures.

2.1.2 Relaxation Ordinance: In 2010, the Kashima City 
authorities enacted a relaxation ordinance to compliment the building standards laws that aimed to preserve the historic characteristics of the two study areas. It released the quasi-fire prevention areas by encouraging changes in city planning. This ordinance led to relaxed regulations for roof structures and reduced restrictions on street construction activities on streets. This was achieved by the adoption of alternative methods, such as the provision of two exits for each traditional house to prevent future fire disasters. Additionally, two-way evacuation routes that connected the houses to designated final evacuation sites (e.g., Hama elementary school) were considered because large-scale disasters require street blockades. However, these routes were not recommended in the ordinance.

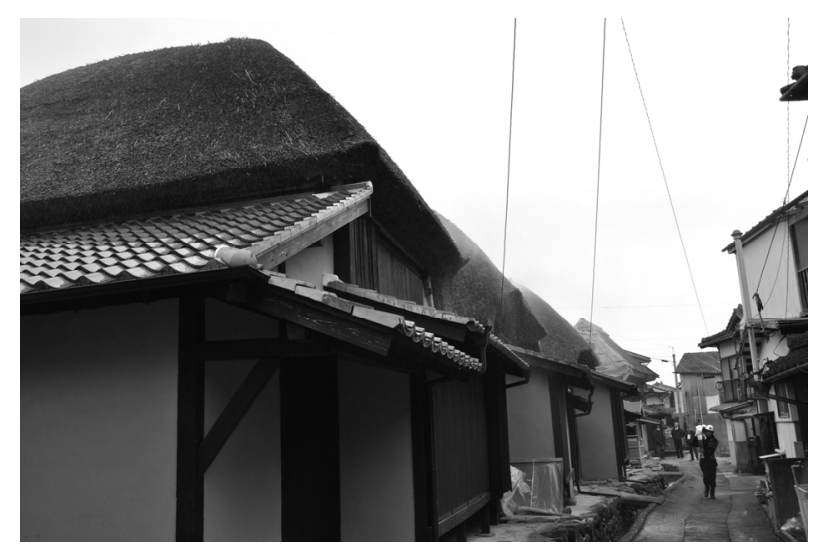

Fig. 1. Study Area A.

Hamashozu Machi Hamakanaya Machi preserved as a local town. Straw-roofed houses alongside streets were built close together.

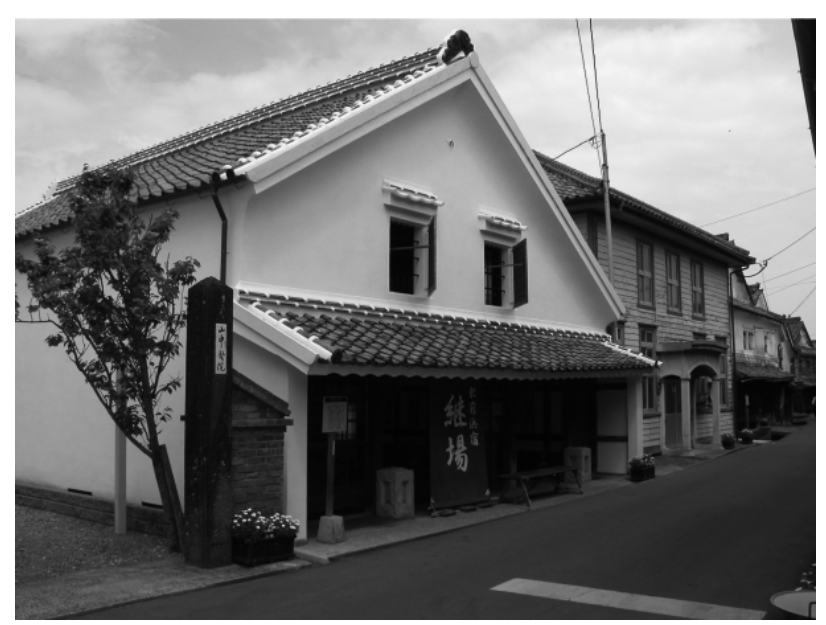

Fig. 2. Study Area B

Hamanaka Machi Happongi Shuku preserved as a sake-producing town. It contains tile-roofed wooden storehouses.

\subsection{Flow of the Study (see Figure 3.)}

2.2.1 Interview Survey: The primary method used in this study was an interview survey conducted with residents of the two study areas. The goal was to determine residents' perceptions of the determination of two-way evacuation routes for each house during large disasters.

The interview survey was conducted between October 2009 and November 2009. Useful data was collected from 21 residents in Study Area A and 35 residents in Study Area B (see Figure 4). During the interview survey, we asked interviewees to describe evacuation routes that connected their homes to temporary safe places based on the procedure shown in Figure 3. The first question asked interviewees to describe their choices of temporary safe places. The second question asked interviewees to describe evacuation routes that connected their houses to temporary safe locations, and, in particular, to describe exits and routes to these temporary safe locations. We asked interviewees to continue until they were unable to find any other evacuation routes. We summarized the results of these interviews on a data sheet (see Figure. 5). The data sheet consisted of a map and photographs of evacuation routes. The map showed exits for houses, route paths, temporary safe places, and route obstacles.

The interviewees provided a variety of answers, such as, "For the first route, I would use the main exit that goes to the front street. For the second route, I would evacuate through the back door and go to my neighbor's garden by walking between the buildings." We categorized all responses into exits, temporary safe places, and the paths located between them. We used the terms, "from," "to," and "through," and classified them respectively in Table 1, based on areas and building types. In this case, building types were categorized as several traditional buildings, single traditional building, and nontraditional building.

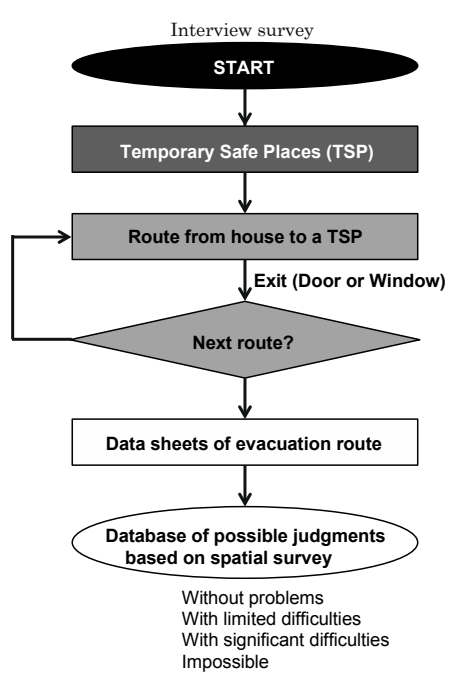

Fig. 3. Flow of study to build database.

2.2.2 Judgments of Possible Evacuation Routes: To create the evacuation route database, we realized that judgments of possible evacuation routes were important. We based our judgments on residents' responses to the interview survey, as well as on the results of a spatial survey. Possible evacuation routes were categorized into the following classifications: "no problems," "with limited difficulties," "with significant difficulties," and "impossible."

A route that contains no problems would be a route that contains a normal exit and path. An example of an evacuation route with limited difficulties would be a route that contains limited gaps, such as a low window and or an engawa (a type of veranda typically included in Japanese houses that is generally located between the garden and the guest room), or a 
route that requires travel through another building. An example of a route with significant difficulties would be a route that contains a high window or a wide stream, or a route that requires travel between buildings. In other words, an impossible route would be too difficult for vulnerable people to travel on. For example, an impossible route would require an individual to exit from a second floor window.

2.2.3 Method of building database and analyzing: We list the results of all possible judgments in Table 1. Therefore, the value of Table 1 is a database that contains evacuation routes with a variety of difficulties for a historic area that includes residents' perceptions. Based on Table 1, we calculated the number of evacuation routes and listed the results in Table 2 . We considered the categories of possible judgments, problems inherent in each route, the order of evacuation routes mentioned by residents, and building types. These calculations can reveal the quantitative realities of study area evacuation routes (e.g., whether primary and other routes were problemfree.

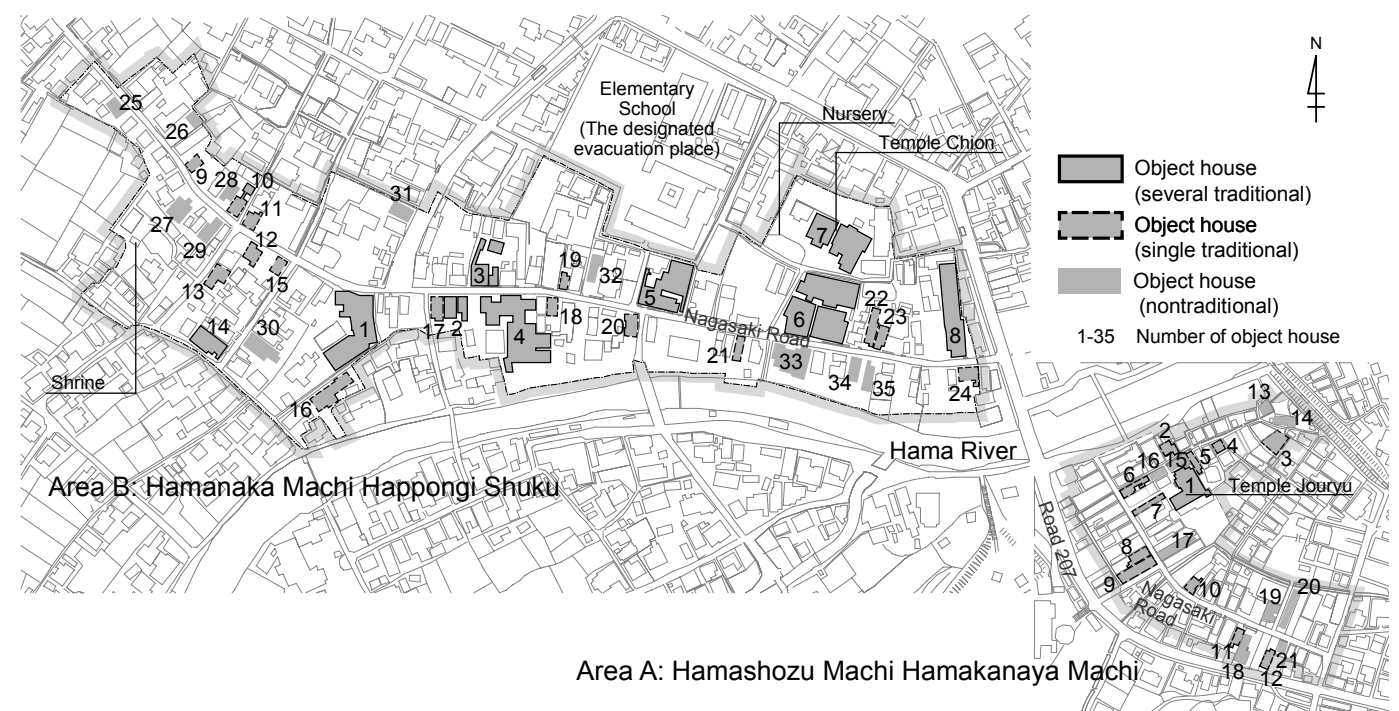

Fig. 4. Object houses of the study area.

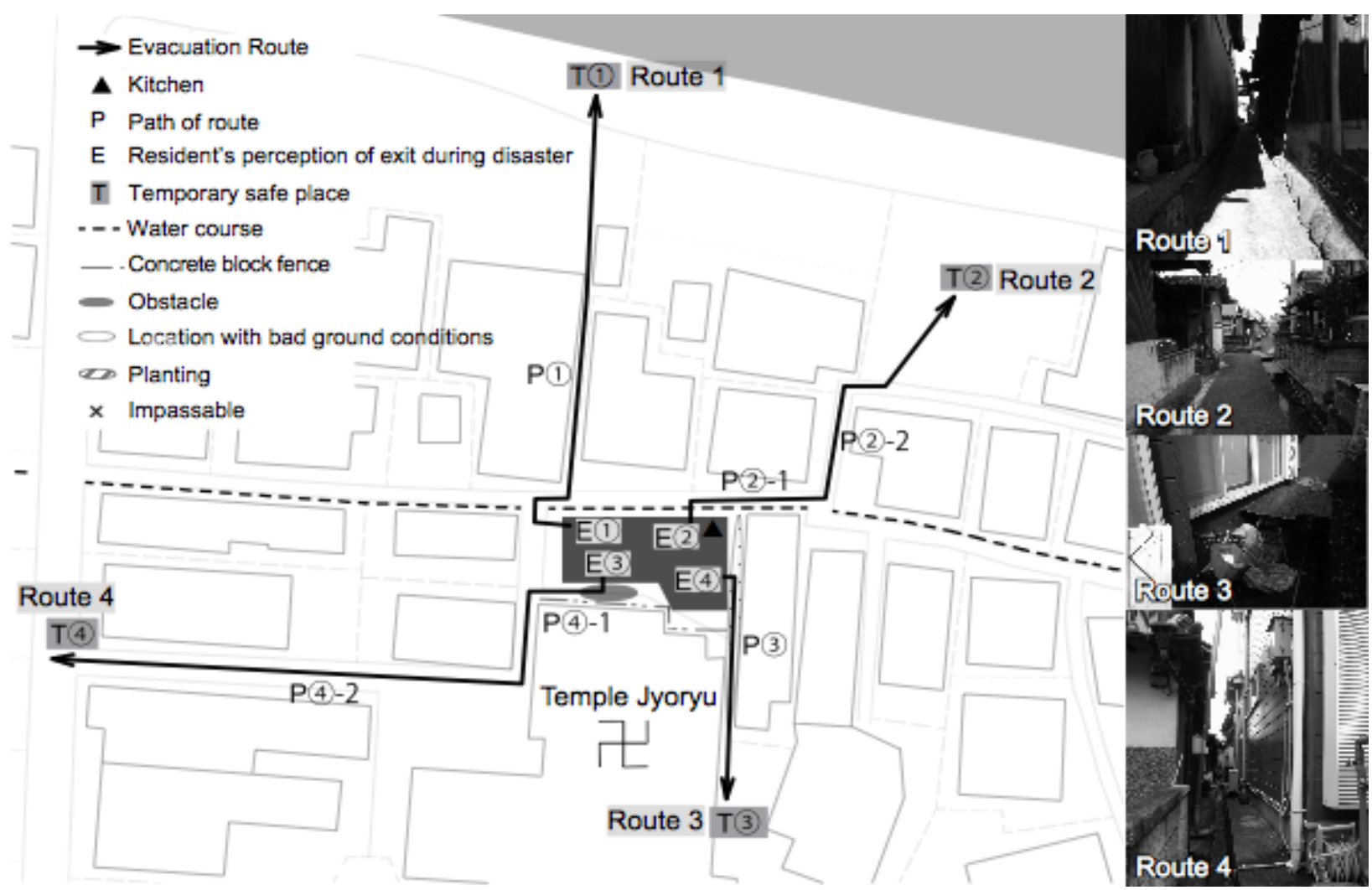

Fig. 5. Sample data sheet (Object House No. 15 located in Area A) 
Table 1. Database of Residents' Determinations of Two-way Evacuation Routes

Area A: Hamashozu Machi Hamakanaya Machi

\begin{tabular}{|c|c|c|c|c|c|c|c|c|c|c|c|c|c|}
\hline \multirow{2}{*}{$\begin{array}{c}\text { Building } \\
\text { Type }\end{array}$} & \multirow{2}{*}{$\begin{array}{c}\text { House } \\
\text { No }\end{array}$} & \multicolumn{3}{|c|}{ Primary route } & \multicolumn{3}{|c|}{ Second route } & \multicolumn{3}{|c|}{ Third route } & \multicolumn{3}{|c|}{ Fourth route } \\
\hline & & From & To & Through & From & To & Through & From & To & Through & From & To & Through \\
\hline $\begin{array}{l}\text { Several } \\
\text { Traditional } \\
\text { Buildings }\end{array}$ & $\begin{array}{c}1 \\
\text { Temple } \\
\text { Jouryu }\end{array}$ & $\begin{array}{l}\text { The main } \\
\text { exit of the } \\
\text { main } \\
\text { building. }\end{array}$ & $\begin{array}{l}\text { The open } \\
\text { space on the } \\
\text { riverside }\end{array}$ & - & The main exit & $\begin{array}{l}\text { Nagasaki } \\
\text { Road }\end{array}$ & - & The engawa & $\begin{array}{l}\text { The Gaboi } \\
\text { wetland }\end{array}$ & - & $\begin{array}{l}\text { The restroom } \\
\text { window }\end{array}$ & $\begin{array}{l}\text { The Gaboi } \\
\text { wetland }\end{array}$ & - \\
\hline \multirow[t]{11}{*}{$\begin{array}{l}\text { Single } \\
\text { Traditional } \\
\text { Building }\end{array}$} & 2 & \begin{tabular}{|l} 
The main \\
exit
\end{tabular} & $\begin{array}{l}\text { Nagasaki } \\
\text { Road or the } \\
\text { road to the } \\
\text { temple }\end{array}$ & - & $\begin{array}{l}\text { The high } \\
\text { window }\end{array}$ & $\begin{array}{l}\text { The street } \\
\text { behind }\end{array}$ & - & $\begin{array}{l}\text { The high } \\
\text { window }\end{array}$ & $\begin{array}{l}\text { The } \\
\text { neighbor's } \\
\text { parking lot }\end{array}$ & - & - & - & - \\
\hline & 3 & $\begin{array}{l}\text { The main } \\
\text { exit }\end{array}$ & $\begin{array}{l}\text { The Hama } \\
\text { River }\end{array}$ & - & $\begin{array}{l}\text { The back } \\
\text { door }\end{array}$ & The front & $\begin{array}{l}\text { Between } \\
\text { the } \\
\text { buildings }\end{array}$ & The engawa & $\begin{array}{l}\text { The Gaboi } \\
\text { wetland }\end{array}$ & - & - & - & - \\
\hline & 4 & $\begin{array}{l}\text { The main } \\
\text { exit }\end{array}$ & $\begin{array}{l}\text { The } \\
\text { neighbor's } \\
\text { parking lot }\end{array}$ & $\begin{array}{l}\text { Along the } \\
\text { path }\end{array}$ & $\begin{array}{l}\text { From the } \\
\text { high window }\end{array}$ & $\begin{array}{l}\text { The street of } \\
\text { the Gaboi } \\
\text { wetland }\end{array}$ & - & $\begin{array}{l}\text { The second- } \\
\text { floor } \\
\text { window }\end{array}$ & $\begin{array}{l}\text { The } \\
\text { neighbor's } \\
\text { house }\end{array}$ & $\begin{array}{l}\text { Via the } \\
\text { roof }\end{array}$ & - & - & - \\
\hline & 5 & $\begin{array}{l}\text { The back } \\
\text { door of the } \\
\text { kitchen }\end{array}$ & $\begin{array}{l}\text { The Gaboi } \\
\text { wetland }\end{array}$ & - & The main exit & $\begin{array}{l}\text { Nagasaki } \\
\text { Road or the } \\
\text { road to the } \\
\text { riverside }\end{array}$ & - & $\begin{array}{l}\text { The side } \\
\text { door }\end{array}$ & $\begin{array}{l}\text { Nagasaki } \\
\text { Road }\end{array}$ & $\begin{array}{l}\text { The } \\
\text { neighbor's } \\
\text { property }\end{array}$ & - & - & - \\
\hline & 6 & $\begin{array}{l}\text { The main } \\
\text { exit }\end{array}$ & $\begin{array}{l}\text { The bridge } \\
\text { or the front } \\
\text { parking lot }\end{array}$ & - & The side door & $\begin{array}{l}\text { The Hama } \\
\text { River }\end{array}$ & - & $\begin{array}{l}\text { From the } \\
\text { back door }\end{array}$ & $\begin{array}{l}\text { The front } \\
\text { street }\end{array}$ & $\begin{array}{l}\text { Between } \\
\text { the } \\
\text { buildings }\end{array}$ & - & - & - \\
\hline & 7 & $\begin{array}{l}\text { The front of } \\
\text { the house }\end{array}$ & $\begin{array}{l}\text { The bridge } \\
\text { over the } \\
\text { Hama River }\end{array}$ & - & The side door & $\begin{array}{l}\text { The Hama } \\
\text { River }\end{array}$ & $\begin{array}{l}\text { The } \\
\text { temple } \\
\text { approach }\end{array}$ & Break & Go outside & \begin{tabular}{|l|} 
The \\
neighbor's \\
wall
\end{tabular} & - & - & - \\
\hline & 8 & $\begin{array}{l}\text { The main } \\
\text { exit }\end{array}$ & $\begin{array}{l}\text { The front } \\
\text { parking lot }\end{array}$ & - & $\begin{array}{l}\text { The back } \\
\text { door }\end{array}$ & $\begin{array}{l}\text { The back } \\
\text { yard }\end{array}$ & - & - & - & - & - & - & - \\
\hline & 9 & $\begin{array}{l}\text { The main } \\
\text { exit }\end{array}$ & $\begin{array}{l}\text { The front } \\
\text { parking } \\
\text { space }\end{array}$ & - & $\begin{array}{l}\text { The back } \\
\text { door }\end{array}$ & $\begin{array}{l}\text { The } \\
\text { neighbor's } \\
\text { vacant lot }\end{array}$ & - & $\begin{array}{l}\text { The second- } \\
\text { floor } \\
\text { window }\end{array}$ & \begin{tabular}{|l|} 
Jump to the \\
outside
\end{tabular} & - & - & - & - \\
\hline & 10 & $\begin{array}{l}\text { The main } \\
\text { exit }\end{array}$ & $\begin{array}{l}\text { The } \\
\text { neighbor's } \\
\text { vacant lot }\end{array}$ & - & $\begin{array}{l}\text { The back } \\
\text { door }\end{array}$ & The garden & - & The engawa & The garden & - & - & - & - \\
\hline & 11 & $\begin{array}{l}\text { The back } \\
\text { door }\end{array}$ & $\begin{array}{l}\text { The } \\
\text { neighbor's } \\
\text { vacant lot }\end{array}$ & - & The engawa & $\begin{array}{l}\text { The } \\
\text { neighbor's } \\
\text { vacant lot }\end{array}$ & - & $\begin{array}{l}\text { The main } \\
\text { exit }\end{array}$ & $\begin{array}{l}\text { The front } \\
\text { neighbor's } \\
\text { parking lot }\end{array}$ & - & $\begin{array}{l}\text { The side } \\
\text { window }\end{array}$ & The street & $\begin{array}{l}\text { The } \\
\text { neighbor' } \\
\text { s lot }\end{array}$ \\
\hline & 12 & $\begin{array}{l}\text { The back } \\
\text { window }\end{array}$ & $\begin{array}{l}\text { The opposite } \\
\text { side of the } \\
\text { street }\end{array}$ & - & The main exit & $\begin{array}{l}\text { The } \\
\text { neighbor's } \\
\text { vacant lot }\end{array}$ & - & $\begin{array}{l}\text { The engawa } \\
\text { beside the } \\
\text { main exit }\end{array}$ & $\begin{array}{l}\text { The front } \\
\text { street }\end{array}$ & - & - & - & - \\
\hline \multirow[t]{9}{*}{$\begin{array}{l}\text { Nontraditional } \\
\text { Building }\end{array}$} & 13 & $\begin{array}{l}\text { The main } \\
\text { exit }\end{array}$ & $\begin{array}{l}\text { The Hama } \\
\text { River }\end{array}$ & - & $\begin{array}{l}\text { The low } \\
\text { window }\end{array}$ & $\begin{array}{l}\text { The Hama } \\
\text { River }\end{array}$ & - & $\begin{array}{l}\text { Several high } \\
\text { windows }\end{array}$ & $\begin{array}{l}\text { May be } \\
\text { used with } \\
\text { difficulty }\end{array}$ & - & - & - & - \\
\hline & 14 & $\begin{array}{l}\text { The main } \\
\text { exit }\end{array}$ & The street & - & The door & $\begin{array}{l}\text { The back } \\
\text { vacant lot }\end{array}$ & - & The engawa & $\begin{array}{l}\text { The } \\
\text { neighbor's } \\
\text { garden }\end{array}$ & - & $\begin{array}{l}\text { The side } \\
\text { window }\end{array}$ & $\begin{array}{l}\text { The open } \\
\text { space near } \\
\text { the Hama } \\
\text { River }\end{array}$ & - \\
\hline & 15 & $\begin{array}{l}\text { The main } \\
\text { exit to }\end{array}$ & $\begin{array}{l}\text { The open } \\
\text { space of the } \\
\text { Hama River }\end{array}$ & The path & $\begin{array}{l}\text { The kitchen } \\
\text { door }\end{array}$ & $\begin{array}{l}\text { The parking } \\
\text { space }\end{array}$ & $\begin{array}{l}\text { Beyond } \\
\text { the street }\end{array}$ & $\begin{array}{l}\text { The side } \\
\text { window }\end{array}$ & $\begin{array}{l}\text { Nagasaki } \\
\text { Road }\end{array}$ & $\begin{array}{l}\text { The } \\
\text { temple } \\
\text { approach } \\
\end{array}$ & $\begin{array}{l}\text { The } \\
\text { bathroom } \\
\text { window }\end{array}$ & $\begin{array}{l}\text { The } \\
\text { neighbor's } \\
\text { garden }\end{array}$ & - \\
\hline & 16 & $\begin{array}{l}\text { The main } \\
\text { exit }\end{array}$ & $\begin{array}{l}\text { Nagasaki } \\
\text { Road }\end{array}$ & - & The engawa & $\begin{array}{l}\text { The front } \\
\text { yard of the } \\
\text { temple } 1\end{array}$ & - & $\begin{array}{l}\text { The back } \\
\text { door }\end{array}$ & $\begin{array}{l}\text { Nagasaki } \\
\text { Road }\end{array}$ & $\begin{array}{l}\text { The } \\
\text { temple }\end{array}$ & - & - & - \\
\hline & 17 & $\begin{array}{l}\text { The front } \\
\text { exit }\end{array}$ & $\begin{array}{l}\text { Nagasaki } \\
\text { Road }\end{array}$ & - & The side door & $\begin{array}{l}\text { The parking } \\
\text { space }\end{array}$ & - & $\begin{array}{l}\begin{array}{l}\text { The back } \\
\text { door }\end{array} \\
\end{array}$ & $\begin{array}{l}\text { The Gaboi } \\
\text { wetland }\end{array}$ & - & - & - & - \\
\hline & 18 & $\begin{array}{l}\text { The main } \\
\text { exit }\end{array}$ & $\begin{array}{l}\text { Nagasaki } \\
\text { Road }\end{array}$ & - & The engawa & Road 207 & - & $\begin{array}{l}\text { The back } \\
\text { door }\end{array}$ & $\begin{array}{l}\text { The } \\
\text { neighbor's } \\
\text { lot }\end{array}$ & - & $\begin{array}{l}\text { Another back } \\
\text { door }\end{array}$ & $\begin{array}{l}\text { The } \\
\text { neighbor's } \\
\text { vacant lot }\end{array}$ & - \\
\hline & 19 & $\begin{array}{l}\text { The main } \\
\text { exit }\end{array}$ & $\begin{array}{l}\text { The front } \\
\text { vacant lot }\end{array}$ & - & $\begin{array}{l}\text { The high } \\
\text { window }\end{array}$ & $\begin{array}{l}\text { The back } \\
\text { vacant lot }\end{array}$ & - & - & - & - & - & - & - \\
\hline & 20 & \begin{tabular}{|l|} 
The main \\
exit
\end{tabular} & $\begin{array}{l}\text { The front } \\
\text { street }\end{array}$ & - & $\begin{array}{l}\text { The high } \\
\text { window }\end{array}$ & $\begin{array}{l}\text { The vacant } \\
\text { lot }\end{array}$ & - & - & - & - & - & - & - \\
\hline & 21 & $\begin{array}{l}\text { The main } \\
\text { exit }\end{array}$ & $\begin{array}{l}\text { The front } \\
\text { open space }\end{array}$ & - & $\begin{array}{l}\text { The back } \\
\text { door }\end{array}$ & $\begin{array}{l}\text { The front } \\
\text { street }\end{array}$ & - & $\begin{array}{l}\text { The high } \\
\text { window }\end{array}$ & The street & - & - & - & - \\
\hline
\end{tabular}

Area B: Hamanaka Machi Happongi Shuku

\begin{tabular}{|c|c|c|c|c|c|c|c|c|c|c|c|c|c|}
\hline \multirow{2}{*}{$\begin{array}{c}\text { Building } \\
\text { Type }\end{array}$} & \multirow{2}{*}{$\begin{array}{c}\text { House } \\
\text { No }\end{array}$} & \multicolumn{3}{|c|}{ Primary route } & \multicolumn{3}{|c|}{ Second route } & \multicolumn{3}{|c|}{ Third route } & \multicolumn{3}{|c|}{ Fourth route } \\
\hline & & From & To & Through & From & To & Through & From & To & Through & From & To & Through \\
\hline \multirow[t]{4}{*}{$\begin{array}{l}\text { Several } \\
\text { Traditional } \\
\text { Buildings }\end{array}$} & 1 & $\begin{array}{l}\text { The shop } \\
\text { exit }\end{array}$ & $\begin{array}{l}\text { The front } \\
\text { street }\end{array}$ & - & $\begin{array}{l}\text { The back } \\
\text { door }\end{array}$ & $\begin{array}{l}\text { The back } \\
\text { open space }\end{array}$ & $\begin{array}{l}\text { The } \\
\text { buildings }\end{array}$ & $\begin{array}{l}\text { The } \\
\text { storehouse } \\
\text { door }\end{array}$ & The street & $\begin{array}{l}\text { The path } \\
\text { beside the } \\
\text { house }\end{array}$ & $\begin{array}{l}\text { The carport } \\
\text { by opening } \\
\text { the shutters }\end{array}$ & $\begin{array}{l}\text { The front } \\
\text { street }\end{array}$ & - \\
\hline & 2 & $\begin{array}{l}\text { The main } \\
\text { exit }\end{array}$ & The street & - & $\begin{array}{l}\text { The kitchen } \\
\text { door }\end{array}$ & $\begin{array}{l}\text { The parking } \\
\text { lot }\end{array}$ & $\begin{array}{l}\text { Between } \\
\text { the } \\
\text { buildings }\end{array}$ & $\begin{array}{l}\text { The side } \\
\text { engawa }\end{array}$ & The street & - & - & - & - \\
\hline & 3 & $\begin{array}{l}\text { The main } \\
\text { exit }\end{array}$ & The street & The shop & $\begin{array}{l}\text { The back } \\
\text { kitchen door }\end{array}$ & $\begin{array}{l}\text { The parking } \\
\text { lot in front of } \\
\text { the storage }\end{array}$ & - & - & - & - & - & - & - \\
\hline & 4 & The shop & $\begin{array}{l}\text { The } \\
\text { elementary }\end{array}$ & $\begin{array}{l}\text { The front } \\
\text { store }\end{array}$ & $\begin{array}{l}\text { The back } \\
\text { door of the }\end{array}$ & $\begin{array}{l}\text { The Hama } \\
\text { river }\end{array}$ & - & $\begin{array}{l}\text { The side } \\
\text { door }\end{array}$ & $\begin{array}{l}\text { The } \\
\text { neighbor's }\end{array}$ & $\begin{array}{l}\text { The } \\
\text { garden }\end{array}$ & - & - & - \\
\hline
\end{tabular}




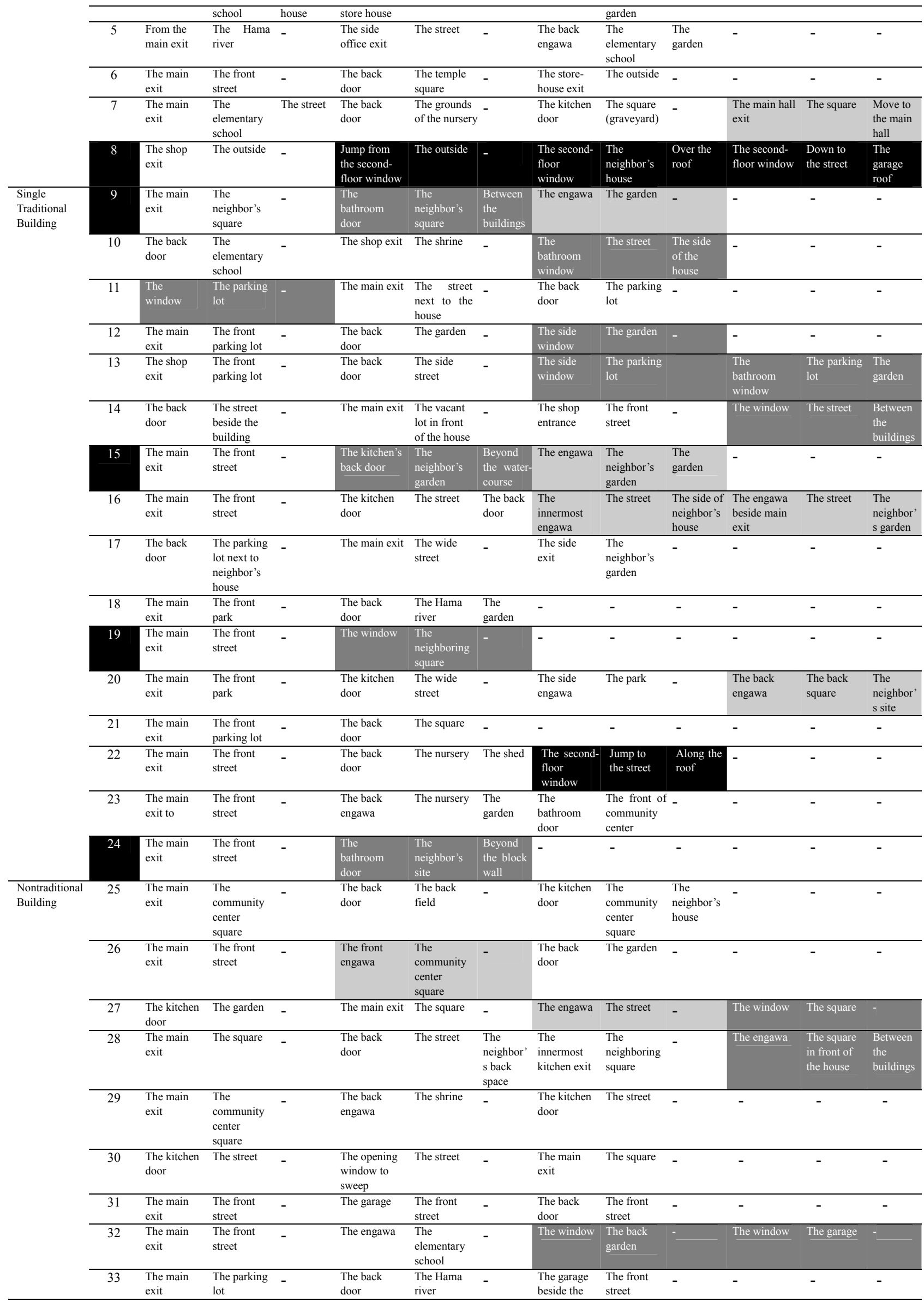




\begin{tabular}{|c|c|c|c|c|c|c|c|c|c|c|c|c|c|}
\hline & \multicolumn{13}{|c|}{ house } \\
\hline & 34 & $\begin{array}{l}\text { The main } \\
\text { exit }\end{array}$ & $\begin{array}{l}\text { The front } \\
\text { street }\end{array}$ & - & $\begin{array}{l}\text { The back } \\
\text { door }\end{array}$ & $\begin{array}{l}\text { The Hama } \\
\text { river }\end{array}$ & - & $\begin{array}{l}\text { The back } \\
\text { engawa }\end{array}$ & $\begin{array}{l}\text { The Hama } \\
\text { river }\end{array}$ & - & The window & The street & - \\
\hline & 35 & $\begin{array}{l}\text { The main } \\
\text { exit }\end{array}$ & $\begin{array}{l}\text { The } \\
\text { community } \\
\text { center } \\
\text { square }\end{array}$ & - & The balcony & The square & - & $\begin{array}{l}\text { The } \\
\text { window }\end{array}$ & The square & - & - & - & - \\
\hline 2 & The white & cter in ble & shows house & & ently possess & wo-way evac & tion rou & & & & & & \\
\hline Route & A route wi & ut problems & & & & & & & & & & & \\
\hline Route & A route wi & imited diffic & ies (e.g., a hig & ste & te that travels th & ough another & uilding) & & & & & & \\
\hline Route & A route wi & ignificant d & culties (e.g., re & uir & $\mathrm{m}$ a high windo & $\mathrm{v}$, between bl & dings) & & & & & & \\
\hline Route & An imposs & route (e.g. & it from the sec & nd & he roof) & & & & & & & & \\
\hline - & No answer & $m$ interview & & & & & & & & & & & \\
\hline
\end{tabular}

\section{ANALYSIS OF THE PRESENT SITUATION}

\subsection{Determination of two-way evacuation routes}

We determined that two-way evacuation routes could not be established for ten houses because of several current conditions: Three single traditional houses and two nontraditional houses were located in Area A. One single traditional house and four nontraditional houses were located in Area B. Two-way escape routes could be established for the remaining 45 houses.

We attempted to determine residents' perceptions of temporary safe places (see Figure 6). We also attempted to evaluate the time required to reach final evacuation locations based on the locations of temporary safe places.

\subsection{Residents' perceptions of evacuation routes}

Based on Tables 1 and 2, our determinations of residents' perceptions of evacuation routes are listed below:

- Only two primary routes contained significant difficulties. The remaining 54 primary routes did not contain evacuation difficulties.

- With respect to secondary routes, five routes contained limited difficulties and ten routes contained significant difficulties. We determined that one route was impossible because it required an individual to exit from a second story window.

- With respect to tertiary routes, eight routes contained limited difficulties, ten routes contained significant difficulties, and five routes were impossible.

- With regard to quaternary routes, 40 residents had no routes, and only one route had no difficulties.

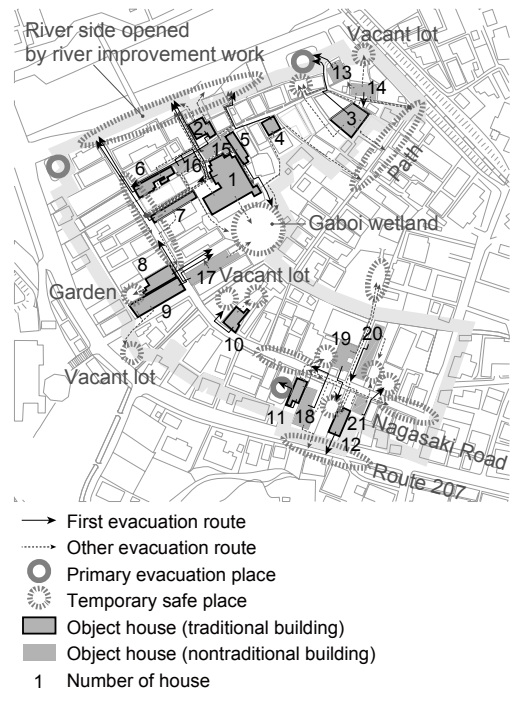

Fig. 6. Temporary safe places in Area A.

Table 2. Results of Calculations Performed on Results Shown in Table 1.

\begin{tabular}{|c|c|c|c|c|c|c|c|c|c|c|c|c|c|c|}
\hline \multirow[t]{2}{*}{ Building Type } & \multirow[t]{2}{*}{ Category } & Problems & \multicolumn{3}{|c|}{ Primary route } & \multicolumn{3}{|c|}{ Second route } & \multicolumn{3}{|c|}{ Third route } & \multicolumn{3}{|c|}{ Fourth route } \\
\hline & & Area & A & $\mathrm{B}$ & Total & A & $\mathrm{B}$ & Total & A & $\mathrm{B}$ & Total & A & $\mathrm{B}$ & Total \\
\hline \multirow{10}{*}{$\begin{array}{l}\text { Several Traditional } \\
\text { Building }\end{array}$} & Route & Route without problems & 1 & 8 & 9 & 1 & 6 & 7 & 0 & 5 & 5 & 0 & 0 & 0 \\
\hline & \multirow{3}{*}{ Route } & Route with limited difficulties & 0 & 0 & 0. & 0 & 0 & 0 & 1 & 0 & 1 & 0 & 2 & 2 \\
\hline & & from the engawa & & & 0 & & & 0 & 1 & & 1 & & 2 & 2 \\
\hline & & from low window & & & 0 & & & 0 & & & 0 & & & 0 \\
\hline & \multirow[t]{3}{*}{ Route } & $\begin{array}{l}\text { Route with significant } \\
\text { difficulties }\end{array}$ & 0 & 0 & 0 & 0 & 1 & 1 & 0 & 1 & 1 & 1 & 0 & 1 \\
\hline & & from high window & & & 0 & & & 0 & & & 0 & 1 & & 1 \\
\hline & & through between buildings & & & 0 & & 1 & 1 & & 1 & 1 & & & 0 \\
\hline & Route & Impossible route & 0 & 0 & 0 & 0 & 1 & 1 & 0 & 1 & 1 & 0 & 1 & 1 \\
\hline & - & No route & 0 & 0 & 0 & 0 & 0 & 0 & 0 & 0 & 0 & 0 & 5 & 5 \\
\hline & & Subtotal & 1 & 8 & 9 & 1 & 8 & 9 & 1 & 8 & 9 & 1 & 8 & 9 \\
\hline \multirow{8}{*}{$\begin{array}{l}\text { Single Traditional } \\
\text { Building }\end{array}$} & Route & Route without problems & 10 & 15 & 25 & 7 & 12 & 19 & 3 & 5 & 8 & 0 & 0 & 0 \\
\hline & \multirow{3}{*}{ Route } & Route with limited difficulties & 0 & 0 & 0 & 1 & 0 & 1 & 2 & 3 & 5 & 0 & 2 & 2 \\
\hline & & from the engawa & & & 0 & 1 & & 1 & 2 & 3 & 5 & & 2 & 2 \\
\hline & & from low window & & & 0 & & & 0 & & & 0 & & & 0 \\
\hline & \multirow[t]{3}{*}{ Route } & $\begin{array}{l}\text { Route with significant } \\
\text { difficulties }\end{array}$ & 1 & 1 & 2 & 3 & 4 & 7 & 2 & 3 & 5 & 1 & 2 & 3 \\
\hline & & from high window & 1 & 1 & 2 & 2 & 1 & 3 & 1 & 3 & 4 & 1 & 2 & 3 \\
\hline & & through between buildings & & & 0 & 1 & 3 & 4 & 1 & & 1 & & & 0 \\
\hline & Route & Impossible route & 0 & 0 & 0 & 0 & 0 & 0 & 3 & 1 & 4 & 0 & 0 & 0 \\
\hline
\end{tabular}




\begin{tabular}{|c|c|c|c|c|c|c|c|c|c|c|c|c|c|c|}
\hline & - & No route & 0 & 0 & 0 & 0 & 0 & 0 & 1 & 4 & 5 & 10 & 12 & 22 \\
\hline & & Subtotal & 11 & 16 & 27 & 11 & 16 & 27 & 11 & 16 & 27 & 11 & 16 & 27 \\
\hline \multirow{11}{*}{$\begin{array}{l}\text { Nontraditional } \\
\text { Building }\end{array}$} & Route & Route without problems & 9 & 11 & 20 & 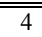 & 10 & $\overline{14}$ & 3 & 8 & 11 & 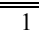 & 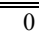 & 1 \\
\hline & & Route with limited difficulties & 0 & 0 & 0 & 3 & 1 & 4 & 1 & 1 & 2 & 0 & 0 & 0 \\
\hline & Route & from the engawa & & & $\overline{0}$ & 2 & 1 & $-\overline{3}$ & 1 & 1 & 2 & & & 0 \\
\hline & & from low window & & & 0 & 1 & & 1 & & & 0 & & & 0 \\
\hline & Route & $\begin{array}{l}\text { Route with significant } \\
\text { difficulties }\end{array}$ & 0 & 0 & 0 & 2 & 0 & 2 & 2 & 2 & 4 & 2 & 4 & 6 \\
\hline & & from high window & & & 0 & 2 & & -2 & 2 & 2 & 4 & -2 & 3 & $-\overline{5}$ \\
\hline & & through between buildings & & & 0 & & & 0 & & & 0 & & 1 & 1 \\
\hline & Route & Impossible route & 0 & 0 & 0 & 0 & 0 & 0 & 0 & 0 & 0 & 0 & 0 & 0 \\
\hline & - & No route & 0 & 0 & 0 & 0 & 0 & 0 & 2 & 0 & 2 & 6 & 7 & 13 \\
\hline & & Subtotal & 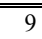 & 11 & 20 & 9 & 11 & 20 & 9 & 11 & 20 & 9 & 11 & 20 \\
\hline & & Total & 21 & 35 & 56 & 21 & 35 & 56 & 21 & 35 & 56 & 21 & 35 & 256 \\
\hline
\end{tabular}

\section{CONCLUSION}

We created a basic evacuation route database to categorize problems that occurred during the determination of two-way evacuation routes. The database was based on current conditions in the two study areas, as well as on residents' perceptions. This database provides basic information that can be used to determine two-way evacuation routes for each study area (e.g., the number of houses that possess two-way evacuation routes that do not contain problems, or the number of houses that possess routes that might be easily renovated without damaging the value of traditional houses.

Furthermore, based on this database, we calculated the evacuation time required to travel from each house to each designated evacuation location to determine the danger residents might encounter on each evacuation route.

\section{ACKNOWLEDGMENT}

This research was supported by Grants-in-Aid for Scientific Research (representative: Assoc. Prof. N. Mishima) and the Program for the Promotion of Methodological Innovation in Humanities and Social Sciences by Cross-Disciplinary Fusing (representative: Prof. K. Kitagawa). In addition, we are thankful for the support and cooperation provided by the Kashima City Authority and by individuals who resided in the study areas.

\section{REFERENCES}

[1] K. Dow and S. L. Cutter, "Crying Wolf: Repeat Responses to Hurricane Evacuation Orders," Coastal Management, vol. 26, no.4, 1998, pp. 237-252.

[2] T. E. Drabek, "Understanding Disaster Warning Responses," The Social Science Journal, vol. 36, no.3, 1999, pp. 515-523.

[3] M. Nara, Y. Ohshima, and M. Watanabe, "Walking Speed Of People in Refuge - Walking on Stairs," Bulletin of Japanese Association of Fire Science and Engineering, vol. 45, no.1-2, 1996, pp. 11-17.

[4] T. Sano, N. Takeichi, T. Kimura, Y. Ohmiya, Y. Yoshida, and H. Watanabe, "Characteristics of Confluence of Two Occupant Flows on Staircases in High-Rise Buildings," Journal Of Architecture And Planning, vol. 598, 2005, pp.
51-56.

[5] D. K. Bird, G. Gisladottir, and D. Dominey-Howes, "Residents' Perceptions of Volcanic Hazards and Evacuation Procedures," Natural Hazards and Earth System Sciences, vol. 9, 2009, pp. 251-266.

[6] D. M. Brommer and J. C. Senkbeil, "Pre-landfall Evacuee Perception of the Meteorological Hazards Associated with Hurricane Gustav," Natural Hazards, 2010.

[7] C. Matyas, S. Srinivasan, I. Cahyanto, B. Thapa, L. Pennington-Gray, and J. Villegas, "Risk Perception and Evacuation Decisions of Florida Tourists Under Hurricane Threats: A Stated Preference Analysis," Natural Hazards, 2011.

[8] L. Chalmet, R. Francis, and P. Saunders, "Network Model for Building Evacuation," Fire Technology, vol. 18, no.1, 1982, pp. 90-113.

[9] H. W. Hamacher and S. A. Tjandra, "Mathematical Modeling of Evacuation Problems: A State of The Art," Pedestrian and Evacuation Dynamics, 2002, pp. 227-266.

[10] C.-A. Tai, Y.-L. Lee, and C.-Y. Lin, "Urban Disaster Prevention Shelter Location and Evacuation Behavior Analysis," Journal of Asian Architecture and Building Engineering, vol. 9, no.1, 2010, pp. 215-220.

[11] T. Kimura, T. Sano, K. Hayashida, N. Takeichi, Y. Minegishi, Y. Yoshida, and H. Watanabe, "Representation Of Crowds In a Multi-Agent Model: Development Of Pedestrian Simulation System Simtread," Journal of Architecture and Planning, vol. 74, no.636, 2009, pp. 371-377.

[12] W. Chiewchengchol, T. Koga, and K. Hirate, "Development of an Evacuation Simulator Using A Walkthrough System and Research On Evacuation Behavior in the Case of Fire," Journal of Asian Architecture and Building Engineering, vol. 10, no.1, 2011, pp. 101-108.

[13] M. Jha, K. Moore, and B. Pashaie, "Emergency Evacuation Planning with Microscopic Traffic Simulation," Journal of the Transportation Research Board, no.1886, 2004, pp. 40-48.

[14] T. Kim, B. S. Kim, and K. Kim, "Smoke Movement and Evacuation Time in the Arcade of a Traditional Market Using Numerical Simulation," Journal of Asian Architecture and Building Engineering, vol. 6, no.2, 2007, pp. 403-410.

[15] S. Kim, B. George, and S. Shekhar, "Evacuation route planning: Scalable heuristics," Proc. the 15th annual 
ACM International Symposium on Advances in Geographic Information Systems, 2007.

[16] G. J. Lim, S. Zangeneh, M. R. Baharnemati, and T. Assavapokee, "A Capacitated Network Flow Optimization Approach for Short Notice Evacuation Planning," European Journal of Operational Research, vol. 223, no.1, 2012, pp. 234-245.

[17] X. Zhou, B. George, S. Kim, J. M. R. Wolff, Q. Lu, and S. Shekhar, "Evacuation planning: A spatial network database approach," Proc. the IEEE Computer Society Technical Comittee on Data Engineering, 2010, pp. 1-6.

[18] T. Okubo, T. Ikemoto, M. Miyajima, M. Gotou, A. Murata, and Y. Suzuki, "A Survey on Disaster Prevention Planning of Historical Town Preservation District Teramachi of Kanazawa City," Disaster Mitigation of Cultural Heritage and Historic Cities, vol. 4, 2010, pp. 311-316.

[19] Y. Toyoda, S. Otsuki, and H. Kanegae, "A Study on Local Safety Increased by Shortening of Evacuation Routes in Case Of Senbon-Syaka-Do Made Use of as an Emergency Evacuation Site," Disaster Mitigation of Cultural Heritage and Historic Cities, vol. 3, 2009, pp. 259-266.

[20] M. Yamasaki, Y. Kurata, H. Otsuki, "A study about the existence of emergency evacuation doors in the backyards of traditional townhouses in Kyoto," Disaster Mitigation of Cultural Heritage and Historic Cities, vol. 5, 2011, pp. 69-72.

[21] N. Mishima, N. Miyamoto, and Y. Taguchi, "Evacuation Route Planning for a Historic Preservation Area in Large Disasters," Journal of Habitat Engineering and Design, Selected paper from ISHED Conference 2012, Shanghai, 2013, pp. 121-128.

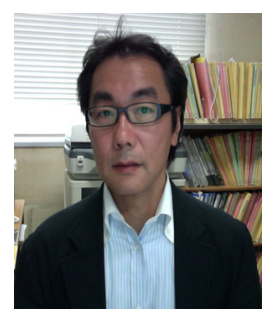

\section{Nobuo Mishima}

He received the B.E., M.E., and D.E. in urban engineering from the University of Tokyo, Japan in 1988, 1990, and 1995 respectively. He was employed by Saga University, Japan as a Lecturer between 1995 and 1998, an Assistant Professor between 1998 and 2007, an Associate Professor between 2007 and 2013, and as a Professor beginning in 2013. His main research interests include urban planning and design.

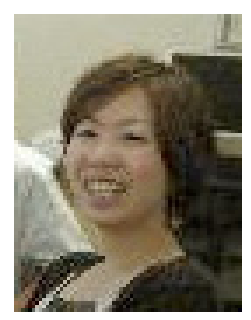

\section{Naomi Miyamoto}

She received the B.E., and M.E. from Saga University, Saga, Japan, in 2010, and 2012 respectively. She is a member of staff at Land Brain Co., which is a consultancy office for city planning in Japan. Her current research interests are city planning and field surveys of historic areas. Her primary field of study is urban planning. She is a member of the Architectural Institute of Japan.

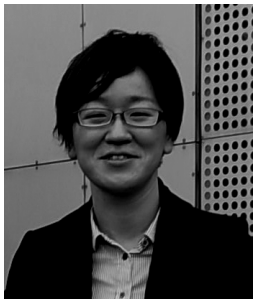

\section{Yoko Taguchi}

She received the B.E., M.E., and D.E. in architecture from Tokyo Institute of Technology, Japan in 1997, 1999, and 2006 respectively. She was employed by Yonago National Collage of Technology, Japan as an Assistant Professor between 2006 and 2008. She was employed by Saga University, Japan as an Assistant Professor between 2008 and 2011, and as a Lecturer beginning in 2011. Her main research interests include architectural planning and design.

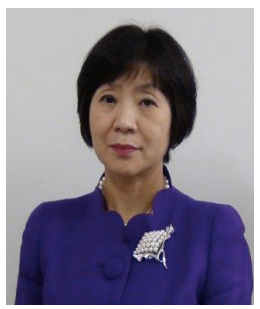

\section{Keiko Kitagawa}

She received the B.S., M.S., and D.S. from Toyo University, Japan in 1973, 1976, and 1979 respectively. She was employed by Koriyama Woman University as a Lecturer between 1979 and 1984. She was employed as an Associate Professor during 1984-94, and as a Adjunct Professor by Lutheran Bible Institute 1987, U.S.A, Professor during 1994-1997. She worked as an Assistant Professor of saga University between 1997-2000 , and as a Professor since 2000. Her main research interests include Gerontology and Social Work.

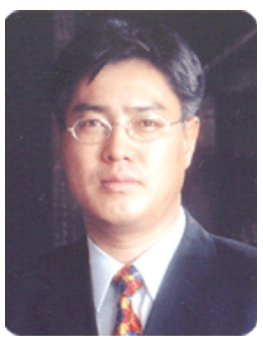

\section{Yong-Sun Oh}

He received B.S., M.S., and Ph.D. degrees in electronic engineering from Yonsei University, Seoul, Korea, in 1983, 1985, and 1992, respectively. He worked as an $\mathrm{R} \& \mathrm{D}$ engineer at System Development Division of Samsung Electronic Co. Ltd., Kiheung, KyungkiDo, Korea, from 1984 to 1986 . He joined the faculty of the Dept. of Information Communication Engineering, Mokwon University, Daejeon, Korea, in 1988. During 1998-1999 he served as a visiting professor of Korea Maritime University, Busan, Korea, where he was nominated Head of the Academic Committee of the Korea Institute of Maritime Information and Communication Sciences. He returned to Mokwon University in 1999 and served as Dean of the Central Library and Information Center from 2000 to 2002 and as Director of the Corporation of Industrial Educational Programs from 2003 to 2005 . He worked as an Invited Researcher at ETRI from 2007 to 2008. Recently he served as President of KoCon from 2006 to 2012, and as Dean of Eng. College and Dean of Management Strategic Affairs of Mokwon Univ. from 2010 to 2012. He is currently a professor of Mokwon University and Head of Prospering Committee of KoCon. His research interests include digital communications and their applications. He is currently interested in personalized e-Learning and variety of convergences. 


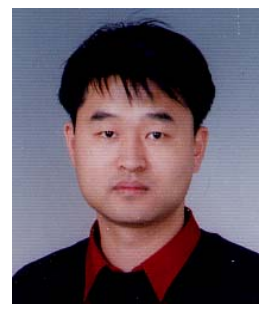

\section{Sun Gyu Park}

After having acquired the degree of the doctor in Tokyo University in September, 2004, he is in office to a professor at Mokwon University division of architecture from March, 2009. The research field is an initial crack prediction of the concrete and reduction technology development, development of the blast furnace slag concrete using alkali activator, a performance enhancement of the recycled aggregate concrete. 